\title{
Morphological and anatomical characteristics of endemic Rosa arabica (Rosoideae, Rosaceae) from Sinai, Egypt.
}

\author{
Eman M. Shamso ${ }^{1 *}$, Ahmed M. Sadek ${ }^{2}$, Hasnaa A. Hosni ${ }^{1}$ \& Abbas A. EL-Ghamery ${ }^{2}$ \\ ${ }^{1}$ Botany \& Microbiology Department, Faculty of Science, Cairo University, Giza, Egypt. \\ ${ }^{2}$ Botany \& Microbiology Department, Faculty of Science, Al-Azhar University, Cairo, Egypt. \\ ${ }^{*}$ Corresponding author: e.shamso@yahoo.com or eshamso@sci.cu.edu.eg
}

\begin{abstract}
Rosa arabica is endemic to the high mountain area of the St. Catherine Protectorate, Southern Sinai, Egypt. It has been listed as Critically Endangered in the IUCN Red Plant List.The present study aimed to provide detailed morphological and anatomical characters of the endemic Rosa arabica by using light and scanning electron microscopy in order to expand knowledge of its taxonomy. The present study revealed the presence of three types of trichomes: simple unicellular, glandular unicellular stalked and glandular multicellular multiseriate. Anomocytic stomata, occasionally hemiparacytic and actinocytic were observed mostly on abaxial surface. Epidermal cells were smooth, with dispersed wax granules and stomata slightly raised with outer stomatal rim. Druses were also reported in pith and cortex of stem and petiole. Achene micromorphology showed scalariform pattern with anastomosed raised anticlinal walls and depressed periclinal walls. These data are presented here for the first time and their taxonomic values are discussed.
\end{abstract}

Key words: Achene, Anatomy, Egypt, Endemic, Rosa arabica, Threatened species, Trichomes

\section{Introduction}

The genus Rosa L. (1753:491) is one of the important genera in the subfamily Rosoideae, family Rosaceae. It comprises four subgenera and aproximately 190 shrubby species distributed widely through temperate and subtropical regions of the northern hemisphere (Jagodziński et al. 2016). The genus has been studied from different points including morphology (Zieliński 1982,Wissemann \& Ritz 2007), cytology (Akasaka 2003), phytochemistry (Mikanagi 2000, Grossi \& Raymond 1998), molecular systematic (Bruneau et al. 2007, Wissemann \& Ritz 2005), pollen and seed morphology (Wrońska-Pilarek 2011, El Ghamery et al.2018); achene morphology (Dowidar et al. 2003, Jagodziński et al. 2016); morphoanatomical characters of achenes (Starikova 1977, 1983, Khrzhanovskii et al. 1985, Zieliński et al. 2010, Guzicka et al. 2012); anatomical characters (Metcalfe \& Chalk 1957, Fatemi et al. 2008).

In Egypt, Rosa arabica Crép. (1869: 344) is endemic to the high mountainous area of St. Catherine Protectorate, southern Sinai, Egypt; with a narrow altitudinal range between 1700 and 2350 m Asl. (El Hadidi 2000, Omar 2014, Mustafa et al. 2001, 2017 and Abdelaal et al.
2019); it has been listed as one of the world's 100 most threatened species, and assessed as Critically Endangered (El Hadidi \& Hosni 2000, Hosni et al. 2013, Omar et al. 2015/16, 2017). The species is severely threatened by both natural factors (long-term drought and climate change) and as a result of human activities (excessive collection, scientific research and over-grazing). This species has an economical value as the leaf, flower and fruit extractions have high medicinal uses due to its active constituents and in addition to its high pastoral importance (Omar 2014, 2017 and Mustafa et al. 2017).

Although the macro- and micro-morphological aspects of $R$. arabica have already been investigated (Täckholm, 1974, Boulos 1999, El Ghamery et al. 2018), the anatomical features of stem and leaves, trichomes and stomatal types as well as achene morphology did not investigate in detail to help in the aid of the taxonomical characters of that species. The present study aims to provide primary documentation of morphological and anatomical characters of the endemic Rosa arabica using both light (LM) and scanning electron microscopy (SEM) to fill the gap in our knowledge of Rosa arabica. 


\section{Morphological and anatomical characteristics of endemic Rosa arabica}

\section{Materials and Methods}

Fresh materials were collected from various localities (Shaq Musa N: $28.32303 \mathrm{E}$ : 33.960, Wadi Tlah N: 28.55321 E: 33.93482 and Wadi El Arbein) in Saint Catherine protected area during April and May 2016 (Map1); the specimens were deposited in the Herbaria of Cairo University (CAI) and $\mathrm{Al}$ Azhar University.

For measurements and calibration stage micrometer was used as well as image $\mathrm{J}$ software and photographed by using stereomicroscope equipped with Premiere MA88-900 digital camera.

For anatomical studies 3-5 specimens of internode and mature blade were taken from basal leaflets. The specimens processed according to paraffin wax method of Johansen (1940) to prepare samples for microtome sectioning at $10-15 \mu \mathrm{m}$ thickness. Sections were fixed on glass slides by means of Haupt's adhesive (1gm gelatin dissolved in $50 \mathrm{ml}$ warm distilled water then $7.5 \mathrm{ml}$ glycerol added + small phenol crystal then kept in refrigerator for 24 hrs. till solidification) and left to dry for 24 hrs. Then sections were stained with Safranin-Fast green standard double stain and mounted in Canada balsam (Sass 1961). For epidermal examination, three pieces of lamina (leaflet) were embedded in $\mathrm{KOH} \mathrm{5 \%} \mathrm{for} \mathrm{24-48} \mathrm{hours;} \mathrm{stomata} \mathrm{and}$ trichomes of upper and lower epidermis were examined. Terminology followed Barthlott (1981, 1990) and Barthlott et al. (1998).

For scanning electron microscopy (SEM), achene and leaflets were mounted on stubs using double-sided adhesive tape, then coated with Nano gold then examined and photographed with JIOL JSM SEM at the Electron Microscope unit at The Regional Center for Mycology and Biotechnology, Al Azhar university, Cairo, Egypt.

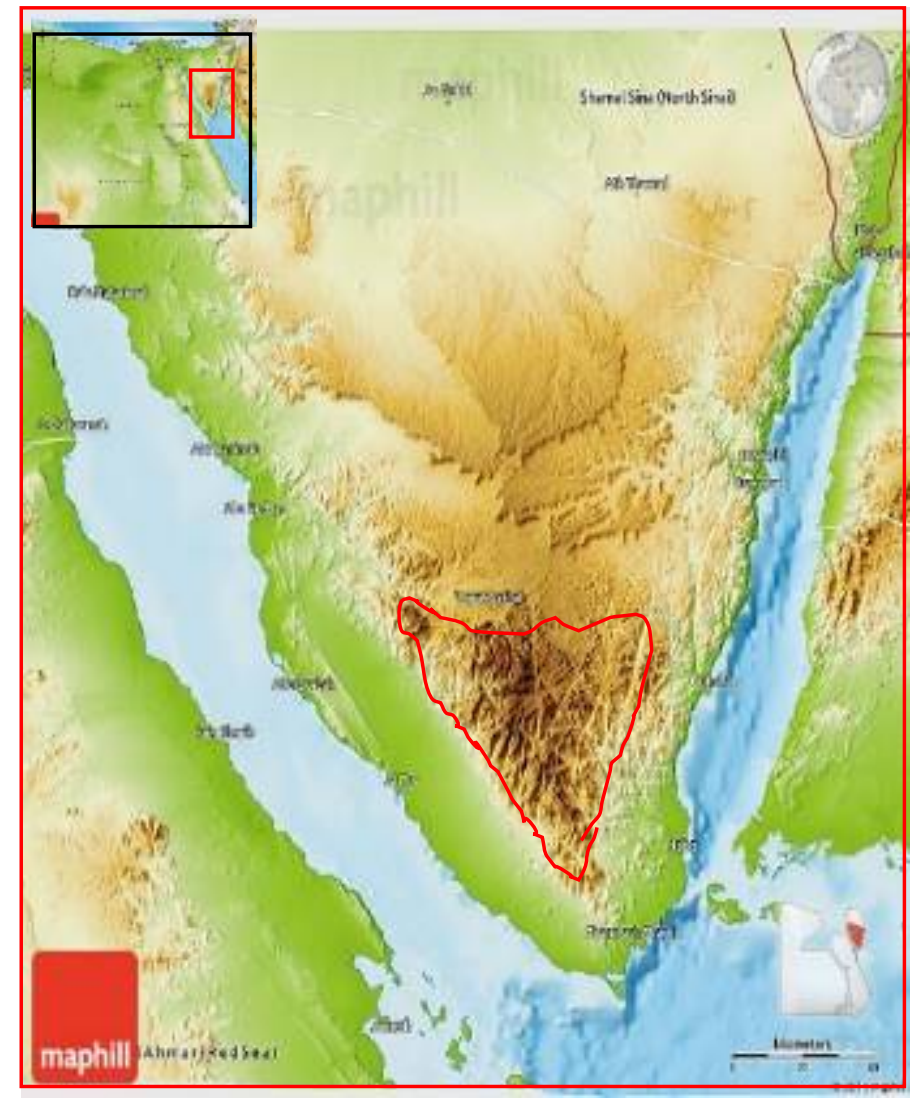

MAP 1: St. Catherine area, Eastern Sinai. 


\section{Results}

Macro- and micro-morphological features:

Perennial shrubs, 50-200 cm tall, much branched. Stem woody, cylindrical, \pm striate, reddish-brown; prickly with sparsely glandular hairs especially at the younger branches. Prickles dense and stout, 5-10 mm long, yellowish to reddish-brown, curved downward. Leaves alternate, imparipinnate with 5-7 leaflets, petiolate; petioles 10-20 mm long, with adnate stipules. Leaflets elliptic 15$30 \times 10-20 \mathrm{~mm}$, with double serrate margin and acute apex, glandular at the lower surface, glabrous with sparsely glandular and eglandular hairs along the midrib at the upper surface (Fig.1a-b); rachis with slender small prickles and glandular hairs. Flowers arranged in dichasial cymes or sometimes solitary. Bract ovate 10-15 × 2-3mm; bracteoles 2, triangular to subulate, $3-8 \times 1.5-2.5 \mathrm{~mm}$, bracts and bracteoles margins subentire with glandular hairs, apex sharply acuminate (Fig.1c-d). Flowers pedicellated, pedicels 7$10 \mathrm{~mm}$ long, with glandular and eglandular hairs. Sepals 5, persistent and reflexed in fruiting stage, ovate, $14-20 \times 2.5-3 \mathrm{~mm}$, basely connate, with 3-4 leafy extensions; villous with long glandular hairs and apex sharp acuminate (Fig.1e-h). Petals 5, free, pale to deep rose, obovate-oblong, 9-10 × 7-8mm, \pm glabrous, with entire margin and emarginate apex. Stamens numerous, filaments $2.5-4 \mathrm{~mm}$ long, glabrous; anthers yellow, bicelled, 1-1.5 $\times 1-1.1 \mathrm{~mm}$, dorsifixed. Carpels numerous, free inside the urn-shaped hypanthium tube, carpels stipitate, gynophore $0.5-0.7 \mathrm{~mm}$ long; ovary oblong, $1.5-2.5 \times 0.5-1 \mathrm{~mm}$; style filiform, 5-6mm long, including the discoid stigma, ovary and style with simple unicellular hairs. Fruit a hip (pometum), consisting of many achenes surrounding by enlarged hypanthium; achene trignous-ovoid, 4-5 × 2$2.5 \mathrm{~mm}$, with acute apex and rounded to truncate base; brown, lustrous, glabrous with little unicellular hairs at the base of the dorsal side, a distinct suture on the ventral side. SEM analysis of achene surface sculpture showed scalariform pattern with anastomosed raised anticlinal walls and depressed periclinal walls. Carpophore 1-2 mm long, glabrous. Seed oblong-cylindrical, 3.5-4 × 1.5-2 mm, brown, dull or faint lustrous, smooth; hilum basal and raised (Fig. 2 a-f).

\section{Anatomical features:}

The epidermal cells under LM were isodiametric with sinuous anticlinal walls on the abaxial surface and straight to wavy on the adaxial surface. Stomata elliptic in outline, 24.7-26.0 × 36.4-39.0 $\mu \mathrm{m}$; nearly confined to the abaxial surface, unevenly distributed; the pattern of stomata was mostly anomocytic, however, hemiparacytic and actinocytic types were occasionally observed. In SEM, Epidermal cells were smooth, with dispersed wax granules and stomata slightly raised with outer stomatal rim (Fig.3a \& b).

In the present study three types of trichomes were recognized: (1) long-stalked glandular with single cell at the tip, is the most common type occurred on rachis of compound leaves, upper midrib of leaflets, flower pedicel, sepals, margins of bract and bracteoles (2) simple unicellular non glandular trichomes found mainly on the leaflet surface, young branches, ovary and style (3) capitate glandular multicellular, multiseriate trichomes were also recorded on leaves (Fig. $3 \mathrm{c}-\mathrm{e}$ ).

Cross section of leaflets showed a well differentiated, uniseriate epidermis covered with cuticle on both surfaces, the cuticle of upper surface is generally thicker than the lower one. (Fig. 4c-d). Mesophyll dorsiventral, consisting of two layers of tightly packed palisade parenchyma making up to half to more than half of leaflet thickness, and 3-4 layers of spongy parenchyma cells with large intercellular spaces. Midrib circular abaxially and adaxial side slightly curved, a small amount of angular collenchyma present on abaxial and adaxial sides. A single large collateral vascular bundle with xylem arranged in 6-7 arches and fibrous sheath of sclerenchyma cells occur as a cap around the phloem tissue. (Fig.4e-f)

In cross section of petiole, the proximal part has a crescent-shaped with winged edges (represented the adnate stipule); 3-4 layers of angular collenchyma cells were present beneath the epidermis. A principal solitary crescent-shaped bundle on median region was observed, accompanied by 2 small subsidiary bundles toward the wings. Few druses were also recorded. 

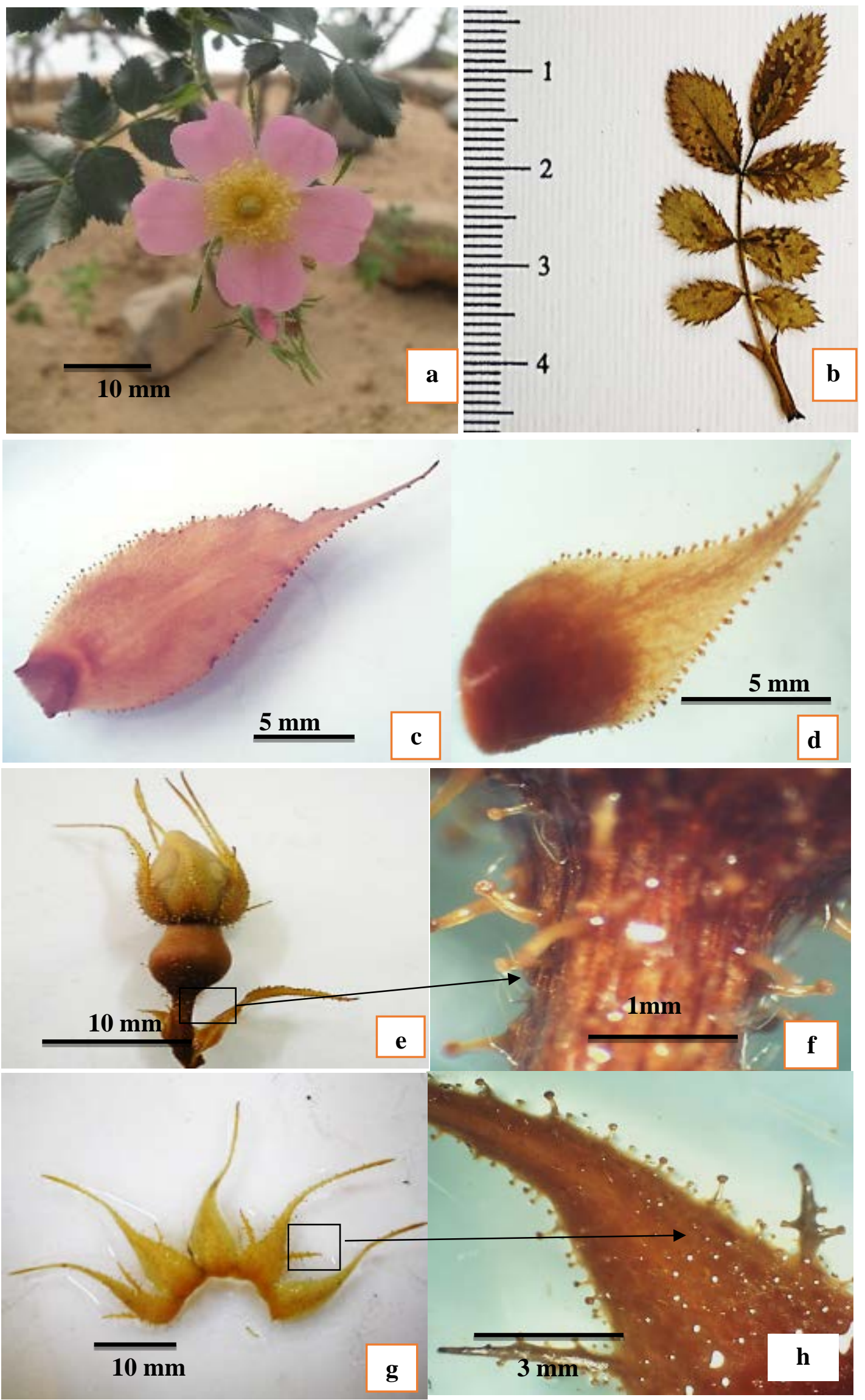

Fig. 1: a. A branch showing leaves and flowers - b. Compound leaf $-\mathbf{c}$. bract $-\mathbf{d}$. bracteole $-\mathbf{e}$. Flowering bud- $\mathbf{f}$. Enlarged part of pedicel showing glandular hairs $-\mathbf{g}$. Calyx - h. Enlarged part of sepal showing leafy extensions and glandular hairs. 


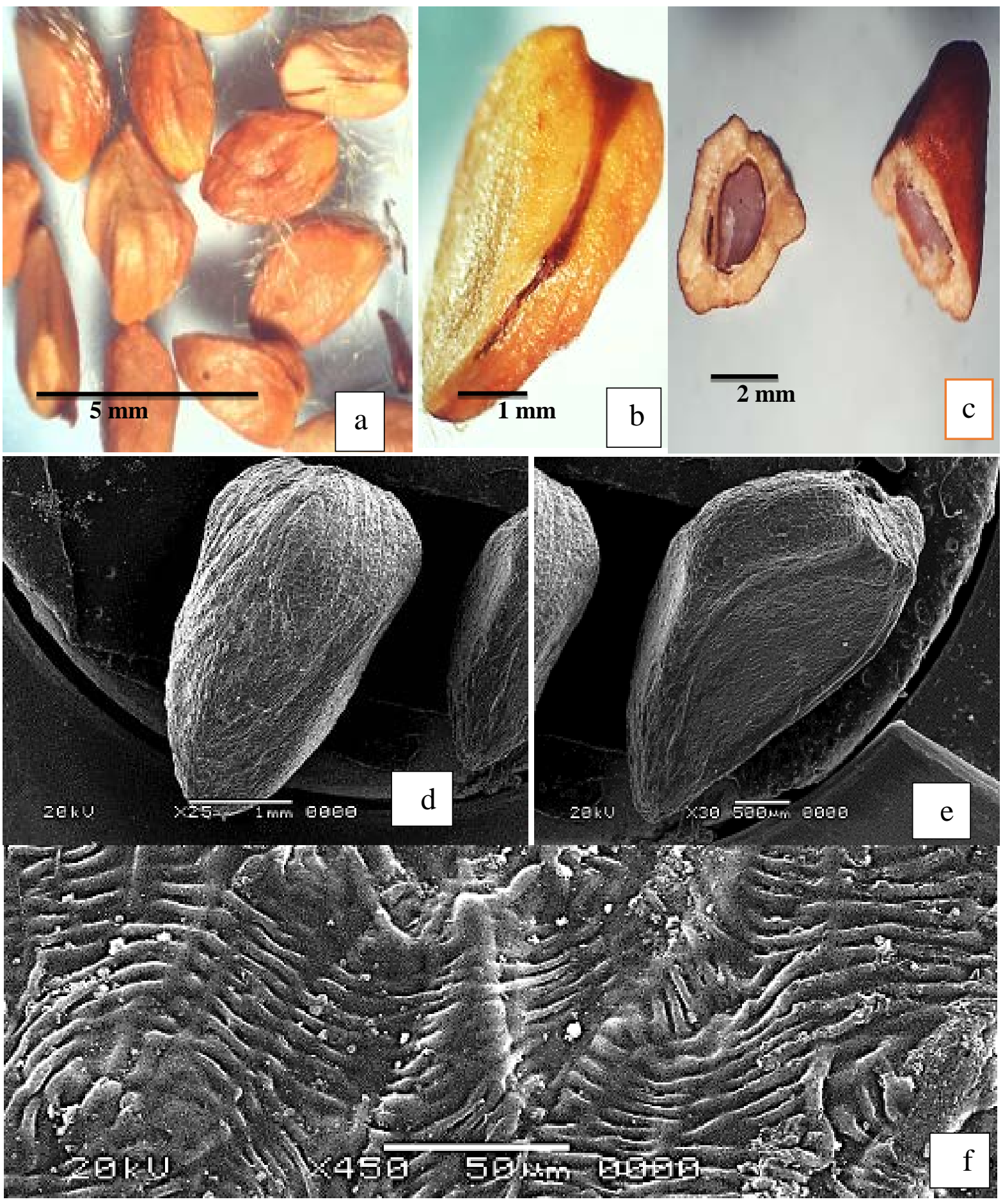

Fig. 2: a-c LM Micrographs of achene to show whole achene with unicellular hairs \& suture (a\&b), Opened achene showing the seed (c) - d-f SEM Micrographs of achene to show dorsal side (d), ventral side (e), Surface sculpture with reticulate-scalariform pattern (f). 


\section{Morphological and anatomical characteristics of endemic Rosa arabica}

Cross section of the stem revealed that the epidermis consists of uniseriate ovoid cells covered with thick cuticle, sometimes interrupted with stomata; a prominent 3-4 layers of angular collenchyma observed next to the epidermis, followed by 5-8 layers of polyhedral parenchyma. Vascular bundles ca.
30, with thin medullary rays in between, consists of 7-8 layers of sclerenchyma followed by phloem and xylem, xylem appears to form a continuous ring; pith wide of parenchymatous cells. Calcium oxalate crystals were found in both cortex and pith. (Fig.4a-d).

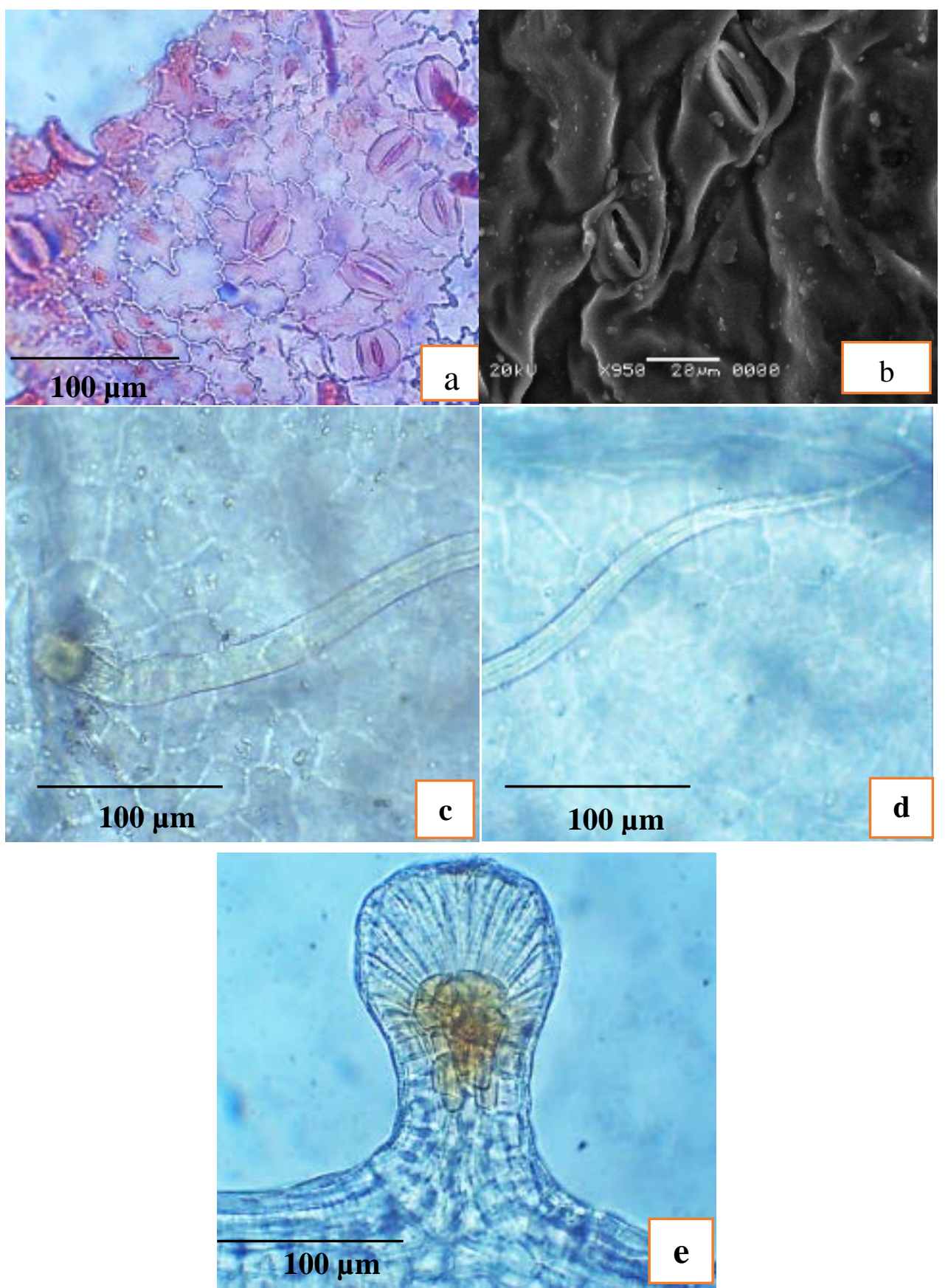

Fig. 3: Micrographs of the leaf surface. a. Epidermal cells and stomata (LM); b. SEM of epidermal cells showing stometal rim and the granular wax; c-d. Unicellular trichomes; e. Capitate glandular multicellular, multiseriate trichome. 

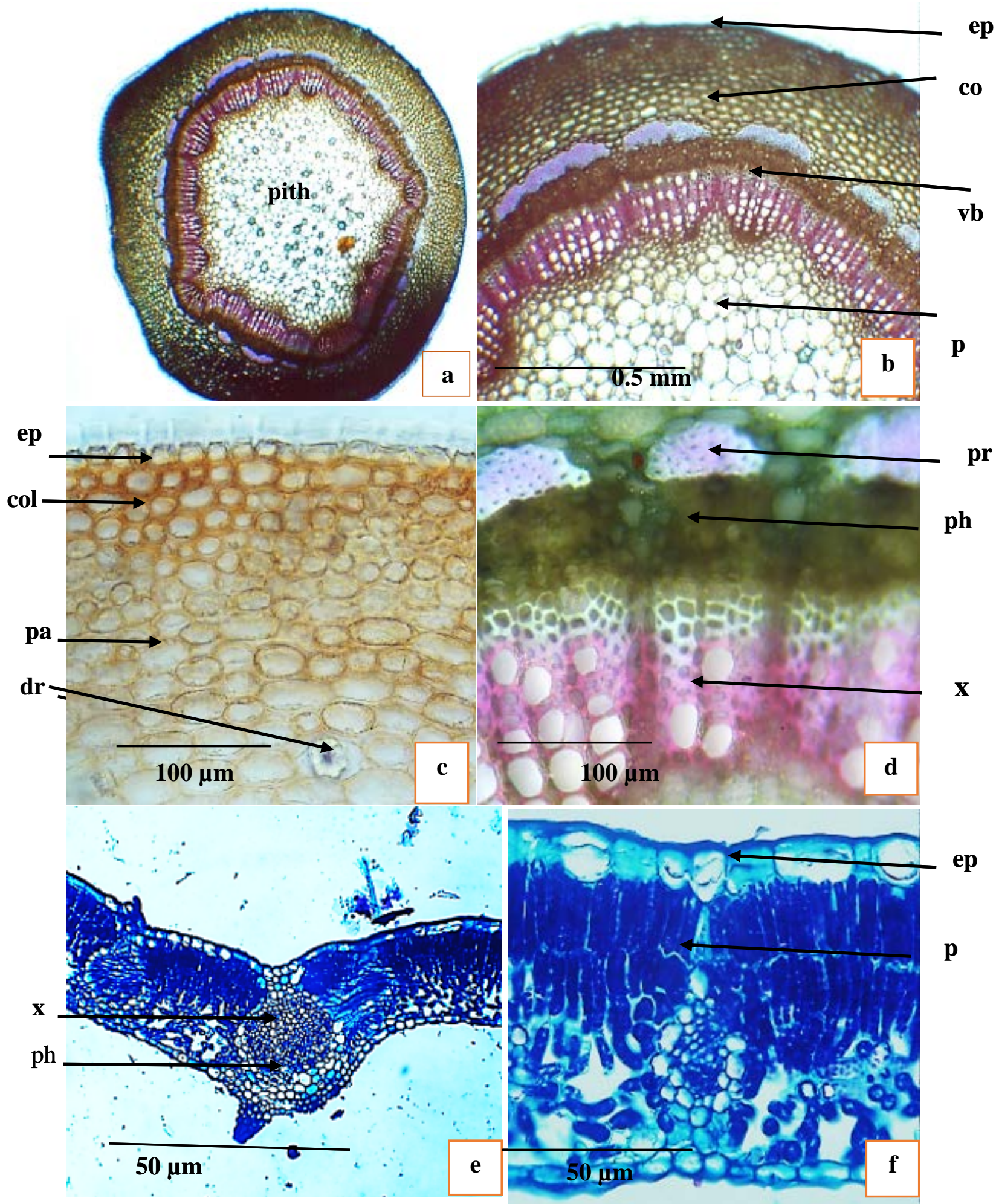

Fig. 4: a\&b. Cross section of stem - c. Enlarged part of cortex showing druses crystal - d. vascular bundle - e. Cross section of Leaflet showing midrib and lamina - f. Enlarged part of lamina. (co: cortex - col: collenchyma - dr: druses - ep: epidermis - pa: parenchyma - ph: phloem - pr: pericyclic fibers - p: palisade tissue $-\mathrm{x}$ : xylem) 


\section{Morphological and anatomical characteristics of endemic Rosa arabica}

\section{Discussion}

The anatomical and morphological characteristics of this work provide the first detailed description of the leaves and achenes for the endemic Rosa arabica. Earlier studies gave a little information for the main morphological features based on stereomicroscope examinations (Täckholm 1974, Boulos 1999).

According to Jagodziński et al. (2016), the morphological characters of achene as well as exocarp sculpture are of a great taxonomic significance in the delimitation of Rosa taxa; they recognized four types of exocarp sculpture within Rosa species: scalariform, reticulae, reticulate-scalariform with raised anticlinal wall and depressed periclinal wall or rarely smooth. In our study another type was recorded: scalariform with anastomosed raised ridges. According to Zielińskiet al. 2010, another specific feature observed in Rosa species is the presence of stomata on pericarp of achenes with limited taxonomic value. In our study no stomata were seen on pericarp of R. arabica.

The anatomical characters are important for the classification of certain problematic taxa at species level in some cases (Metcalfe \& Chalk 1957, Stace 1980, Ganeva et al. 2009, Song \& Hong 2018). Stomata were anomocytic (ranunculaceous), a type recorded for the Rosaceae, although other types recorded in the family (Ganeva et al. 2009). Another two types: hemiparacytic and actinocytic stomata types were also recorded for the first time in the present study. The diversity and abundance of trichomes make them ideal objects for investigations in plant morphology and anatomy, providing information on taxonomy, ecology and physiology. Three types of trichomes were recorded: simple unicellular, glandular with long stalked and capitate glandular multicellular multiseriate. Our findings showed that the trichomes on ovary and style were simple unicellular, whereas glandular trichomes were distributed on margins of bracts, bracteoles, sepals, lower surface of leaflets and young branches. Simple unicellular hairs were also observed on midrib of the leaflet upper surface and flower pedicels mixed with glandular hairs. Adumitresei et al. (2009) pointed out that the glands present on Rosa species produce scented volatile oils. The presence of calcium oxalate crystals (druses) were reported by many authors in leaves of most genera of Rosaceae (Metcalfe \& Chalk 1957, Faghir et al. 2011, Song \& Hong 2018), in the present study druses were also reported in pith and cortex of stem and petiole.

\section{Conclusion}

This study is the first detailed description of the morphological and anatomical features of the endemic species Rosa arabica, hoping that these findings will contribute to our knowledge for systematic purposes and it may help in the protection of endemic plants which are under threat.

\section{Acknowledgment}

The authors extend their thanks to Dr. Amal Hosny, the Herbarium, Botany \& Microbiology Department, Faculty of Science, Cairo University for the critical revision of the manuscript.

\section{References}

Abdelaal, M., Foisa, M., Fenu, G. \& Bacchetta, G. 2019. Using MaxEnt modeling to predict the potential distribution of the endemic plant Rosa arabica Crép. in Egypt. Ecological informatics 50:68-75.

Adumitresei, L., Gostin, I., Aprotosoaie, C., Şpac, A., Stănescu, I. \&Toma, C. 2009. Chemical compounds identified in the leaf glands of Rosa agrestisSavi and Rosa rubiginosaL. Annalestiintifice ale Univeritatii"Al.I. Guza" Iasi Tome LV, fasc.1, s.IIa. Biologievegetala: 39-48.

Akasaka, M. 2003. Karyotype analysis of wild Rosa species belonging to septets B, C, and D by Molecular Cytogenetic Method. Breeding Science 53:177-182.

Barthlott, W. 1981. Epidermal and seed surface characters of plants: systematic applicability and some evolutionary aspects. Nordic Journal of Botany 1: 345-355.

Barthlott, W. 1990. Scanning electron microscope of the epidermal surface in plants in: Claugher, D. (Ed.), Scanning electron 
microscopy in taxonomy of functional morphology. Clarendon, Oxford. pp. 69-83

Barthlott, W., Neinhuis, C., Cutler, D., Ditsch, F., Meusel, I., Theisen, I. \&Wilheimi, H. 1998. Classification and terminology of plant epicuticular waxes. Botanical Journal of Linnaean Society. 126:237-260.

Boulos, L. 1999. Flora of Egypt. Vol. 1, AlHadara publishing, Cairo, Egypt.419 pp.

Bruneau, A., Starr, J.R. \&Joly, S. 2007. Phylogenetic relationships in the genus Rosa: new evidence from chloroplast DNA sequences and an appraisal of current knowledge. Systematic Botany32(2):366-378. http://dx.doi.org/10.1600/0363644077811796

\section{$\underline{53}$}

Crepin, F. 1869. Primitiaemonographiae Rosarum. - Matériauxpourservir à l'Histoire des Roses. [Premier fascicule.] Bulletin de la Sociétéroyale de Botanique deBelgique t. 8: 226-349.

Dowidar, A., Loutfy, M., Kamel, E., Ahmed, A. \& Hafez, H. 2003. Studies on the Rosaceae I. seeds and/or Achene Macro and Micromorphology. Pakistan Journal of Biological Science 6(20): 1778-1791.

El Ghamery A.A., Hosni H.A. \&Sadek A.M. 2018. Pollen and Seed Morphology of some Endemic Taxa in Saint Catherine.Taeckholmia. 38: 40-60.

El Hadidi, M.N. 2000. Flora Aegyptiaca. Vol. 1, Part 1. The Palm Press \& Cairo University, Herbarium, Cairo, pp. 187

El Hadidi, M.N. \& Hosni, H. 2000. Conservation and threats. In: El Hadidi, M.N. (Ed.). Flora Aegyptiaca. Vol. 1, Part 1. The Palm Press \& Cairo University Herbarium, Cairo. pp. 105-151.

Faghir, M.B., Attar, F. \&Ertter, B. 2011. Foliar anatomy of genus PotentellaL. (Rosaceae) in Iran and its taxonomic implication. Iranian Journal of Science and Technology 3:243-256

Fatemi, N., Attar, F., Assareh, M.H.\&Hamzeh'ee, B.2008. Comparative anatomy of leaf and rachis of Rosa L. (Rosaceae) in Iran as taxonomical implication. Iranian Journal of Botany 14(2):156-164.
Ganeva, Ts., Uzonova, Kr., \& Koleva, D. 2009. Comparative leaf anatomy investigations in species of genus Crategeus (Rosaceae) from Bulgaria.FeddesReportorium 120(3-4): 169-184

Grossi, C. \& Raymond, O. 1998. Flovonoid and enzyme polymorphism and taxonomic organisation of Rosa section: Carolinae, Cinnamomeae, Pimpinellifoliae and Synstylae.Biochemical Systematic \& Ecology 26:857-871.

Guzicka, M., Zieliński, J.,Tomaszewski, D.\&Gawlak, M. 2012. Anatomical study on the developing pericarp of selected Rosa species (Rosaceae). Dendrobiology 68: 77-87 Hosni H., Hosny A., Shamso E. \&Hamdy R. 2013. Endemic and near-endemic taxa in the flora of Egypt. Egyptian Journal of Botany53:357-383.

Jagodziński, A. M., MaciejewskaRutkowska, I., Wrońska-Pilarek, D. \&Bocianowski, J. 2016. Taxonomic significance of achene morphology of selected Rosa taxa (Rosaceae) occurring in Poland. ActaSocietatisBotanocorumPoloniae85(2):34 93. http://dx.doi. org/10.5586/asbp.3493

Johansen, D.A. 1940. Plant Microtechnique. McGraw-Hill Book Co., New York.790 pp.

Khrzhanovskii, V.G., Ponomarenko, S.F. \& Kolobov, E. $\quad$ S. 1985. Mikromorfologicheskayakharakteristikaplodo vshipovnika v svyazi s sistematikoiroda Rosa L. Byulleten Glavnogo Botanicheskogo Sada 137:47-53 in Russian

Linnaeus, C. 1753.Species Plantarum.Vol. 1. Laurentii Salvii, Holmiæ.560 pp.

Metcalfe, C. R. \& Chalk, L. 1957. Anatomy of Dicotyledons II. Clarendon Press, Oxford. 557 pp.

Mikanagi, Y. 2000. Anthocyanins in flowers of genus Rosa, sections Cinnamomeae (=Rosa), Chineses, Gallicanae and some modern garden roses. -Biochemical Systematic \& Ecology 26:887-902.

Mustafa, A. A., Zaghloul, M.S., El-Wahab, R.A. \& Shaker, M. 2001. Evalution of plant diversity and endemism in Saint Catherine protectorate, South Sinai, Egypt. Egypt. J. Bot. 41:121-139. 
Mustafa, A. A., Zaghloul, M.S., Mansour, S.R., Al Sharkawy, D.H. \& Alotaibi, M. 2017. Long term monitoring of Rosa arabica populations as a threatened species in South Sinai, Egypt. Egypt. J. Biodivers. Endangr. Species. 5:1-8

Omar, K.A. 2014. Evaluating the effectiveness of in-situ conservation on some endemic plant species in south Sinai, Egypt.American Journal of Life Science 2(3):164-175

Omar, K.A., Sayed, A., Abdallah, A., Aboelfetoh, G. \& Abdallah, M. 2015/2016. In Omar, K. (ed.) Ecological and Conservation Assessment of Rosa arabica in St Katherine-Egypt, Final Report 1-84. Conservation Leadership Programme, Birdlife International, Fauna \& Flora International and Wildlife Conservation Society.

Omar, K.A. 2017. Rosa arabica. The IUCN Red List of Threatened Species 2017: e.T84120072A84120074. http://dx.doi.org/10 .2305/IUCN.UK.2017-3.RLTS.T84120072

A84120074.en.

Sass, J.E. 1961. Botanical microtechnique.3 ${ }^{\text {rd }}$ ed. ThemIowa state college press. Ames. 228 pp.

Song, J. \& Hong, S. 2018. Comparative petiole anatomy of the tribe Sorbarieae (Rosaceae)provide new taxonomically informative characters. Nordic Journal of BotanyVol 36(5):1-14. doi:10.1111/njb.01702
Starikova, V.V. 1977. Morphologoanatomical characterization of nutlets of some Rosa species (Rosaceae). Botanichesky Zhurnal 62:1500-1504.

Starikova, V.V. 1983. Morphologicalanatomical characteristics of nutlets in some species of Rosa (Rosaceae). Botanichesky Zhurnal 68:522-524.

Täckholm, V. 1974. Students' Flora of Egypt. ${ }^{\text {nd }}$ ed. Cairo University.888 pp.

Wissemann, V. \& Ritz, C.M. 2005. The genus Rosa (Rosoideae, Rosaceae) revised: Molecular analysis of nrITS-1 and atpBrbcLintergenic spacer (IGS) versus conventional taxonomy. Botanical Journal of Linnaean Society147:275-290.

Wissemann, V. \& Ritz, C.M. 2007. Evolutionary patterns and processes in the genus Rosa (Rosaceae) and their implications for host-parasite co-evolution. Plant Systematics \&Evolution 266:79-89.

Wronska-Pilarek, D. 2011. Pollen Morphology of polish native species of the Rosa genus (Rosaceae) and its relation to systematics. Acta Societatis Botanicorum Poloniae.80(3): 221-232.

Zieliński, J. 1982. Rosa in: Rechinger, K.H. (Ed.) Flora Iranica152:13-31- Graz.

Zieliński, J., Tomaszewski, D., Guzicka, M. \& Maciejewskarutkowska, I. 2010. Stomata on the pericarp of species of the genus Rosa L. (Rosaceae). Plant Systematics andEvolution 284(1-2): 49-55. doi:10.1007/s00606-0090234-0. 